\title{
GLYPHOSATE USE IN FOREST PLANTATIONS
}

\author{
Marcelo Kogan ${ }^{1}$, and Claudio Alister ${ }^{1 *}$
}

\begin{abstract}
Under Chilean conditions the lack of weed control at forest tree establishment results in an average of at least $60 \%$ less biomass accumulation during the first year of growth of radiate pine or eucaliptus, and glyphosate offers a series of advantages in forestry weed management because its activity in both herbaceous weed groups, monocots and dicots, as well as annuals, biennials and perennials. Also, its efficacy in woody undesirable vegetation makes glyphosate a very important herbicide that can be applied to control herbaceous and woody weeds as pre-planting and during the second or third years of trees growth as strip applications. The aim of this review is to discuss the main uses of glyphosate in reforestation worldwide, during the first $2 \mathrm{yr}$ after tree establishment, as broadcast application over the top of the forest trees and the most important factors that could affect glyphosate efficacy as a forest herbicide, like weed growth stage, application technique, volume and water quality, rainfastness, dew effect and the use of extra adjuvant with formulated glyphosate.
\end{abstract}

Key words: Pine, eucalyptus, rainfastness, woody plants.

\section{INTRODUCTION}

Weed management in forest crops has been applied for more than 40 years. Presently, it is widely recognized that all forest plantations should be sustainably managed. To achieve this goal, site management practices should consider several fundamental principles, like protecting the soil from erosion and loss of fertility, and at the same time give appropriate inputs to reach the desired level of annual growth rate (Nambiar, 1995). Plant growth can be improved substantially with appropriate management practices such as site preparation, fertilization and weed control.

The influence of weed control on productivity can be mainly explained in relation to competition for site resources, especially, water and nutrients (Nambiar and Sand, 1993). Weeds adversely affect $\mathrm{N}$-uptake by trees, and thereby aggravate N-deficiency (Smethurst and Nambiar, 1989).

Under Chilean conditions after completing 17 field experiments established from Bío Bío Region to the Los Lagos Region $\left(36^{\circ} \mathrm{S}, 72^{\circ} \mathrm{W}\right.$ to $42^{\circ} \mathrm{S}, 73^{\circ} \mathrm{W}$ ) it was demonstrated that lack of weed control at establishment resulted in an average of $60 \%$ less biomass accumulation

${ }^{1}$ Universidad de Viña del Mar, Centro de Investigación Agrícola y Ambiental (CIAA), Viña del Mar, Chile. *Corresponding author (calister@uvm.cl).

Received: 4 January 2010.

Accepted: 13 October 2010. during the first year of growth of radiate pine (Pinus radiata D. Don). Also, it was clearly documented that total area pre-plant herbaceous weed control produced larger increase in biomass index than the conventional spot gun application (Kogan and Figueroa, 1997).

The length period of time required to convert a forest site back to timber in Chilean forestry, is influenced by the Mediterranean climate, which is characterized by two primary seasons: cold and rainy condition in winter and dry and warm weather in summer. During dry period most weeds and other undesirable vegetation compete with young forest plants. It is a prudent measure to continue controlling weeds until canopy closure starts to occur and trees start to dominate or suppress weeds growth and establish a woodland environment (Haig et al., 1990; Willoughby and Dewar, 1995). The time needed to achieve that condition will depend on tree species, space between rows, site characteristics and initial starting tree growth. The critical advantage in establishing trees free of weed competition compared with no vegetation management may be that canopy closure will occur several years earlier (Harmer and Kerr, 1995). Also reducing competition from undesirable vegetation, thereby allowing the young tree to get adequate moisture and nutrient, can considerably shorter the time required to bring a new forest into production, whichever the management objectives are (Marer et al., 1995).

A "good starting" is essential to maximize forest plant growth. Total weed control with herbicides is desirable 
for plantation in areas likely to encounter severe summer drought (Newton and Knight, 1981), being soil moisture the most limiting factor. Under Mediterranean conditions weeds that growth during winter and spring will deplete soil moisture causing serious deficiency during late spring and summer if rainfall was poor during the warmer season.

It has been normally considered that it is not necessary to undertake herbaceous weed control for more than $1 \mathrm{yr}$ and the first two seasons of forest trees without moisture stress are enough to assure the plantation. Others insist a third year of weed control is required. However, it is not only a matter of knowing how many years of weed control are required, but also the intensity of this practice should be considered. Increasing the width of the weed control strip (spanning the tree row) increased $\mathrm{N}$-uptake by trees. Because of this in a high $\mathrm{N}$ supply conditions (fertile soils), intense weed control is being unnecessary in plantations beyond second year of age and strip weed control could be a better option than complete weed control in managing weeds in young plantations of radiata pine. Weed control in a $1 \mathrm{~m}$-wide strip is sufficient to relief water stress in trees during the initial 2-3 yr after planting. Undoubtedly, this cannot be considered as a recipe (Kogan et al., 2002). Thus, Balneaves and Henley (1992) found the largest increases in radiate pine diameter, height, stem volume and volume per hectare were obtained $7 \mathrm{yr}$ after planting by weed control over the entire area. Nevertheless there is no doubt that under dry summers and non-fertile sites weed control intensity (WCI) should be a striking factor. Kogan et al. (2002) after conducting a field experiment to quantify the effect of different WCI during the first three growing season in a radiate pine plantation, found stem volume index of check trees was similar to plants received spot application in the first and second year. On the other hand, when plots were treated with herbicide spot applications (first year) plus band or total area applications (second year), the stem volume index was twice larger, respectively (Table 1). However, if the first year WCI consisted of total area application the second and third year treatment had less effect on trees growth. The largest biomass yield was obtained when plot were

Table 1. Weed control intensity (WCI) based mainly in glyphosate and its effect on radiata pine stem volume index $\left(\mathrm{dgh}^{2} \mathrm{~h}^{-1}\right)$ during trial (planting 28 June 1996) (adapted from Kogan et al., 2002).

\begin{tabular}{|c|c|c|c|c|c|}
\hline \multicolumn{2}{|c|}{$1996 / 1997$} & \multicolumn{2}{|c|}{$1997 / 1998$} & \multicolumn{2}{|c|}{$1998 / 1999$} \\
\hline June 1996 & 320 DAP & July 1997 & 680 DAP & July 1998 & 1040 DAP \\
\hline WCI & $\mathrm{dm}^{3}$ & WCI & $\mathrm{dm}^{3}$ & WCI & $\mathrm{dm}^{3}$ \\
\hline No control & $0.013 \mathrm{a}$ & No control & $0.64 \mathrm{~d}$ & No control & $4.4 \mathrm{~g}$ \\
\hline Spotgun appl. ${ }^{1}$ & $0.061 b$ & No control & $0.9 \mathrm{~d}$ & No control & $3.3 \mathrm{~g}$ \\
\hline- & - & - & - & Spotgun appl. & $3.5 \mathrm{~g}$ \\
\hline- & - & Spotgun appl. & $1.6 \mathrm{~cd}$ & No control & $5.5 \mathrm{~g}$ \\
\hline- & - & - & - & Spotgun appl. & $5.3 \mathrm{~g}$ \\
\hline- & - & Band appl. $^{2}$ & $3.04 \mathrm{c}$ & No control & $9.4 \mathrm{fg}$ \\
\hline- & - & - & - & Band appl. & $11.4 \mathrm{fg}$ \\
\hline- & - & Total area appl. & $4.91 b$ & No control & $16.0 \mathrm{ef}$ \\
\hline- & - & - & - & Total area appl. & 17.1def \\
\hline Total area appl. ${ }^{3}$ & $0.31 \mathrm{c}$ & No control & $5.61 \mathrm{~b}$ & No control & 23.0cde \\
\hline- & - & - & - & Total area appl. & $31.1 \mathrm{bc}$ \\
\hline- & - & Spotgun appl. & $5.82 \mathrm{~b}$ & No control & $26.1 \mathrm{~cd}$ \\
\hline- & - & - & - & Spotgun appl. & $30.2 b c$ \\
\hline- & - & Band appl. & $6.58 \mathrm{ab}$ & No control & $30.0 \mathrm{bc}$ \\
\hline- & - & - & - & Band appl. & $36.3 \mathrm{ab}$ \\
\hline- & - & Total area appl. & $8.21 \mathrm{a}$ & No control & $44.4 \mathrm{a}$ \\
\hline- & - & - & - & Total area appl. & $39.7 \mathrm{ab}$ \\
\hline
\end{tabular}

$\mathrm{DAP}=$ days after planting.

Means of a given column by the same letter are not significantly different $(\mathrm{P}=0.05)$ according to Duncan multiple comparison test.

${ }^{1}$ Spotgun treatment $\left(1 \mathrm{~m}^{2}\right.$ around each pine tree) in June 1996 corresponded to hexazinone $2.0 \mathrm{~kg}^{-1}$ applied $45 \mathrm{DAP}$. In the second and third year spotgun treatments corresponded to glyphosate $0.87 \mathrm{~kg}^{\mathrm{ai} \mathrm{ha}}{ }^{-1}$ around each tree, avoiding to make contact with them.

${ }^{2}$ Band application was carried out applying glyphosate in a strip $2 \mathrm{~m}$ wide (1-m to each side of the trees), also avoiding to contact the trees.

${ }^{3}$ Total area application at the first year corresponded to glyphosate $1.0 \mathrm{~kg}$ ai ha ${ }^{-1}$ applied $1 \mathrm{wk}$ before planting. In the second and third year this WCI corresponded to glyphosate applied to the whole area, avoiding spray pine trees. 
submitted to total area WCI during the first and second year, independent of weed management during the next 2 yr. On the other hand, considering slope erosion, it appears reasonable according to these data giving to radiate pine the best conditions for establishment, which means total area weed control in the first season, and just a band treatment (1 m-wide strip) during the second year to avoid or decrease risk soil erosion. Under Chilean conditions, if these first 2 years weeds are killed at the right time, it is highly probable that a third year of chemical weed control could be unnecessary.

\section{Glyphosate as a forestry worldwide herbicide}

Of the different alternatives for vegetation management, progressively more attention has been focused on chemical weed control and actually the use of herbicide is intensive for forest establishment. The phenoxyacetic acids, 2,4-D and 2,4,5-T, served for this purpose for more than $30 \mathrm{yr}$, until 2,4,5-T was banned in several countries in the early 1970s. At this time, glyphosate ( $N$-(phosphonomethyl) glycine) appeared as the alternative. This herbicide offered a series of advantage, because its activity in both weeds groups, monocots and dicots, as well annuals, biennials and perennial herbaceous species. Also, its efficacy in some woody undesirable vegetation makes glyphosate a very important herbicide. Also its effect on stump-sprouting species (Fraxinus excelsior L., Betula spp.) after the cutting and the sprouting of Eucalyptus stump can be highly reduced applying to the cut surface glyphosate from 10 to $50 \%$ in water. This is also true after cutting brushwood on trees to eliminate or reduced their growth capacity.

Glyphosate can be applied to control herbaceous and woody weeds as pre-planting to establish forest trees in ex-arable and improved grassland site and reforestation conditions after timber production. Also, can be applied during the second or third years of trees growth as a strip applications and to control selectively: cut stumps, frill-griddle for large undesirable trees and less common glyphosate tree injection.

Use of glyphosate in ex-arable and improved grassland site. In this condition, soils are frequently more fertile compared with traditional replant forest sites and have large weed seed banks. Because of this, heavy weed infestations are common after preparing the site for planting, as well as numerous herbaceous weed species (annuals, biennials and perennials) will germinate, emerge and growth, competing from the beginning with forest plant seedlings. To prevent competition, a preplanting treatment of glyphosate at relatively low rate (1.1 to $1.44 \mathrm{~kg}$ ai ha $^{-1}$ ) at early post weed emergence in mixture with the right soil-active herbicide will allow to control perennial herbaceous weeds to obtain soil persistence effect on newly weed emergence from seeds. The main soil-active herbicides, at least in Chile, that have been used as glyphosate partners belong to the triazine group, mainly simazine, atrazine and terbutilazine. These three herbicides are very selective to pine, and eucalyptus is tolerant enough under agroclimatic conditions in the South of Chile. Nevertheless, simazine and atrazine have been lately banned as herbicide for those Forestry Companies that have certified their plantations through the Forest Stewardship Council (FSC). Other soil-active products like flumioxazin, diclosulam and isoxaflutole could be considered.

Glyphosate in the mentioned mixtures provides a wide spectrum of control, including herbaceous perennials that start growing as soon as site soil preparation takes place. These species are not controlled by Triazines or by most of the other soil-active herbicides. Examples of those species are: Arrhenatherum elatius var. bulbosum, Agrostis spp., Achillea millefolium, Rumex acetosella, Chrysanthemum leucanthemum, Hypochaeris spp. Also glyphosate would complement the soil active herbicides in controlling most of all grasses.

In the other countries where different species of the Pinus are planted (ex. Pinus taeda), there is also the possibility to use Imidazolinone herbicides, because those forest species are tolerant enough to that group of herbicides. Therefore some of the imidazolinone herbicides could also be used as a tank mix with glyphosate as pre-planting treatment.

Pre-planting treatment for herbaceous weed control can be applied to the whole area or just a strip application. Weed control intensity discussed before will depends on several factors, technical and economicals, but should be maintained at least the first $2 \mathrm{yr}$ after planting to ensure tree growth.

Use of glyphosate in reforestation. Before the adoption of chemical weed control, brush control was carried out by hand method; cutting with specific tools ("knifes") those plants at the base. This operation was very difficult, labor demanding, and then highly expensive. Besides, most of the woody species re-growth later in the first year of the plantation making them a real problem because of the limited selective herbicide treatments available to be used in most forest trees.

Generally, foresters view brush weeds as the most difficult competitive plants to manage in reforestation programs. In this situation herbicide treatments can also carried out a pre-planting release, to control especially woody species (shrubs or brush). Domination by shrub and brushes hardwood tree species is the second successional stage following removal of a closed forest canopy by 
logging or wildlife, but also grasses and other herbaceous dicots species will establish themselves. Table 2 shows a partial list of some common shrubs and trees weed species growing in productive forest sites in Chile.

Table 2. Important shrubs and tree weed species in forest sites in Chile.

\section{Chile}

Acacia dealbata

Cytisus scoparius

Cytisus striatus

Rosa rubiginosa

Rubus constrictus

Rubus ulmifolius

Teline monspessulana

Ulex europaeus

Several hardwood trees

(Gevuina avellana, Nothofagus spp., Ulmus spp.)

Source: Marer et al. (1995); Kogan and Figueroa (1999).

Because of the various shrubs and tree weed species, before recommending glyphosate as a pre-planting release treatment; oneself must be sure about glyphosate efficacy in the different species that can be present, as not all of them are equally susceptible to this herbicide. Moreover, complete brush control is seldom achieved with a single herbicide application because of the diversity of species and age at most sites. For that reason glyphosate at rate from 1.44 to $2.5 \mathrm{~kg}$ ai ha ${ }^{-1}$ is often applied as a tank mix with metsulfuron-methyl (Sulfonylurea), or with triclopyr, clopiralyd, fluroxypyr (Pyridines). Glyphosate is particularly effective against Rubus spp., Laniova spp., Pueraria lobata, Acer saccharum, Rosa multiflora, Campsis radicans, Salix spp. Some brush species cannot be effectively controlled with herbicides (e.x. Diospyros spp., Sassafras albidum), and addition management techniques are necessary (Table 3) (CPCR, 1987).

Glyphosate recommended rate for brush and trees control can vary according to the target species and stage of development. However, most of the time there is several species growing together. For this reason the rate can markedly vary according to species susceptibility to glyphosate from: a) $1.8-2.1 \mathrm{~kg}$ ai ha-1 (more susceptible species), b) $2.5-2.88 \mathrm{~kg}$ ai ha ${ }^{-1}$ (moderate susceptible species), and c) 3.3-4.0 ai ha ${ }^{-1}$ (more tolerant species). The highest rate should be preferred if plants are larger than the adequate size for optimum results or weed density is really high. This herbicide should be applied when woody plants are actively growing, after full leaf expansion or after regrowth $( \pm 50 \mathrm{~cm}$ height). Table 4

Table 3. Response to glyphosate of woody brush and undesirable tress.

\begin{tabular}{lll}
\hline Susceptible & Moderate susceptible & Tolerant \\
\hline Alnus spp. & Acacia greggii & Diospyros spp. \\
Acer saccharum & Acer rubrum & Sassafras aibidum \\
Baccharis consanguinea & Acer circinatum & \\
Cytisus scoparius & Fraxinus spp. & \\
Campsis radicans & Gevuina avellana & \\
Prunus emarginata & Liriodendron tulipifera & \\
Prunus serotina & Mimulus guttatus & \\
Prunus pensylvanica & Nothofagus spp. \\
Pueraria lobata & Oxydendrum arboreum & \\
Populus tremuloides & Polystichum munitum & \\
Quercus palustris & Parthenocissus quinquefolia & \\
Quercus rubra & Quercus velutina & \\
Rhus radicans & Quercus alba & \\
Rosa multiflora & Robinia pseudoacacia & \\
Rubus spp. & Rhamnus purshiana & \\
Salix spp. & Rhus copallinum & \\
Teline monspessulana & Rhus vernix & \\
& Rhus glabra & \\
& Ulex europaeus & \\
& Ulmus spp. &
\end{tabular}

Adapted from CPCR $(1987 ; 2001)$ and own data. 
Table 4. Recommended pre-planting glyphosate treatments to control some brush and woody trees (adapted from Kogan and Figueroa, 1999).

Type of undesirable vegetation Herbicide treatments

Teline monspessulana and Aristotelia chilensis ${ }^{1}$

Rubus spp., Rosa moschata and Cytisus scoparius ${ }^{1}$

Ulex europaeus and trees (Ulmus glabra, Nothofagus spp., Gevuina avellana, Luma apiculata $)^{1}$
Glyphosate $1.08 \mathrm{~kg}$ ai ha-1

Glyphosate $0.9 \mathrm{~kg}$ ai ha ${ }^{-1}+$ Triclopyr $0.6 \mathrm{~kg}$ butoxyethyl ester ha ${ }^{-1}$

Glyphosate 1.4 ai ha ${ }^{-1}+$ Triclopyr $1.5 \mathrm{~kg}$ butoxyethyl

ester ha ${ }^{-1}$ (add a non-ionic surfactant)

${ }^{1}$ Native species in some circumstances growth in forest sites. Unfortunately in those situations are considered as undesirable vegetation.

shows an example of brush and trees chemical control recommendation in Southern Chile (Kogan and Figueroa, 1999).

During the year of pinus establishment (after woody species were controlled) is common in Chile, before of the FSC certification, to apply a band treatment of hexazinone + atrazine or a mixture of haloxifop-methyl + clopyralid + atrazine or terbutilazine. In the case of Eucalyptus were normally applied glyphosate + simazine or glyphosate + fluroxipyr + simazine. All these treatments will control a wide spectrum of herbaceous weeds. Preventive measures should be taken to avoid contact of glyphosate or any other non selective product with forest trees. Actually other herbicides like isoxaflutole, flumioxazin and diclosulam have been introduced to replace herbicides like hexazinone and triazines.

Glyphosate uses during the first 2 years after tree establishment. The use of glyphosate in the second and third year after forest establishment will depends on weed species that will prevail. Authors experience indicates if pre-planting weed control was effectively done, most of weeds that will trait the plantation will be herbaceous weeds (monocot and dicot, annuals, biennials and perennials) and a minimum of brush and tree regrowth.

Herbaceous weeds will start emerging as soon as rains occur in the fall, and their growth rate will depend on temperature. Cold winters do not favor weeds growth. A new flush of herbaceous weeds will emerge from early spring throughout beginning of summer. These weeds could be mainly competitive in those cases which rains fail to occur at the end of spring. As a result of this there is no guaranty of water supply for forest trees summer growth. During the first 2 years after establishment all these weeds must be controlled to assure appropriate tree rate growth and get a quick soil cover (canopy).

If brush and/or tree regrowth control is required glyphosate can be applied alone or in mixture with metsulfuron-methyl or Pyridine herbicides (triclopyr, clopiralyd, fluroxypyr), when regrows reach at least 1-m height. This application is locally oriented to any regrowth on the bands or in the interrows. All precautions must be taken to avoid contacting forest trees with the spray or with drift. Using anti-drift nozzles and do not apply in windy days is a duty.

To control herbaceous weeds glyphosate plus soil active herbicide could be recommended to the band or total area, during the mid fall. The band has to be treated carefully, avoiding any contact of glyphosate with forest trees. Contractors work with specialized operator that most of the times are able to apply directing the spray, avoiding contacting the small trees. As a result a very limited damage can be produced that is largely compensated because of the plantation rate growth. The interrows, if they are treated, can be treated with a shielded boom sprayer, also equipped with anti-drift nozzles, if topography allows.

A second application, at the beginning of spring, in the same season may be required. This can be performed spraying just the plantation band with glyphosate. Doing this program most of the growing season can be cover and allow the forest trees to growth without competition for water and nutrient.

Use of glyphosate as broadcast application over the top of forest trees. Radiata pine and Eucalyptus spp. are susceptible to over the top glyphosate application. It is interesting to discuss this type of treatment performed in other countries. The most commercially important conifers in USA, like Norway spruce (Picea abies), Sitka spruce (Picea sitchensis), Shots pine and fir (Pseudotsuga spp.) are tolerant enough for standard glyphosate applications. Rate of glyphosate should be reduced at least by $10 \%$ under high temperature $\left(>24-25{ }^{\circ} \mathrm{C}\right)$ at application time and expected hot temperatures the first $24 \mathrm{~h}$ after applications to ensure sufficient tolerance to glyphosate by the conifers (Lund-Hoie, 1982 cited by Lund-Hoie, 1985). Radosevich et al. (1980) studied the selectivity of glyphosate applied at different phenological stages of development of six coniferous species (Ponderosa pine, Jeffrey pine, Sugar pine, Douglas-fir, White fir, and Red fir). All of them were more tolerant to glyphosate after 
fall dormancy, and pine species were more tolerant to fall glyphosate applications. Unfortunately $P$. radiata is not tolerant to allow over the top applications of glyphosate.

Other uses of glyphosate in forest plantations. Stumps of many brushwood species may rapidly sprout after cutting. Glyphosate, at concentration of $8-10 \%$ in water, applied to the stump surface after cutting will eliminate or reduce sprouting of the most deciduous trees (Lund-Hoie, 1985). Also, after Eucalyptus timber (is being harvested) stumps rapidly regrowths. In these cases glyphosate at $50 \%$ in water will prevent re-growth from Eucalyptus stumps (Kogan, unpublished data). This treatment is most effective applied immediately after the tree or brush is cut.

Trunk injection often helps glyphosate to penetrate through the tree bank. In some cases the herbicide may serve as a chemical girdle. The frill treatment consist of a single line of overlapping downward ax cut around the base of the tree, then glyphosate is sprayed or squirted into the cut around the entire trunk of the tree. This method is being used for large trees. A program based in a solution 1-2 $\mathrm{mL}$ of $20 \%$ glyphosate in water per injection or on the ax cut with a frequency of $1 \mathrm{~mL}$ for each $5 \mathrm{~cm}$ of the steam diameter can offer very good results on most deciduous trees, especially in the early summer. Glyphosate can be applied alone or in mixture with growth regulator herbicides, according to tree susceptibility.
Some factors that could affect glyphosate efficacy as forest herbicide

Glyphosate is a fundamental herbicide for weed management in forest establishment and during the initials 2 or $3 \mathrm{yr}$ of growth, because of a series of extraordinary and unique characteristics, among them its weed spectrum, its active translocation, almost no detectable soil activity, very low leaching because its strong soil adsorption, reduce soil half-life, and because is a herbicide with low environmental risk. However, there are some factors that could affect its efficacy. Application techniques, environmental conditions and weed stage of growth, volume and water quality, and use of coadjuvants can determine the success of glyphosate applications.

Weed growth stage. Most of annual weed species are very susceptible to glyphosate. However, there is a very specific response according to different weeds and growth stages. In general, glyphosate should be applied to actively growing grass and broadleaf weeds, and for maximum forestry benefit, it should be apply when weeds are 15 $\mathrm{cm}$ or less in height. Better results may be obtained when more of the weeds are exposed to glyphosate solution. Weeds not contacted by glyphosate will not be affected, as can occur in dense clumps (severe infestations) or when the height weeds and the taller avoid glyphosate reaches the smaller ones. Table 5 shows the required rate of glyphosate to achieve control of different herbaceous

Table 5. Rate of glyphosate isopropylamine (IPA salt) required to control various herbaceous weeds.

\begin{tabular}{|c|c|c|}
\hline \multicolumn{3}{|c|}{ Rate (kg ai ha-1) } \\
\hline 0.72 & 1.08 & $1.5-2.88$ \\
\hline Bromus spp. $(15 \mathrm{~cm})^{1}$ & Cerastium vulgatum $(15 \mathrm{~cm})$ & Sida spinosa $(7 \mathrm{~cm})$ \\
\hline Sisymbrium altissimum $(15 \mathrm{~cm})$ & Senecio vulgaris $(15 \mathrm{~cm})$ & Geranium carolinianum $(30 \mathrm{~cm})$ \\
\hline Hordeum vulgare $(30 \mathrm{~cm})$ & Conyza canadensis $(15 \mathrm{~cm})$ & Eleusine indica $(30 \mathrm{~cm})$ \\
\hline Cenchrus spp. $(30 \mathrm{~cm})$ & Thlaspi arvense $(15 \mathrm{~cm})$ & Richardia scabra $(30 \mathrm{~cm})$ \\
\hline Sorghum bicolor $(30 \mathrm{~cm})$ & Sisymbrium irio $(15 \mathrm{~cm})$ & Cassia obtusifolia $(30 \mathrm{~cm})$ \\
\hline Eragrostis cilianensis $(30 \mathrm{~cm})$ & Lolium multiflorum $(15 \mathrm{~cm})$ & Erodium spp. $(30 \mathrm{~cm})$ \\
\hline \multirow[t]{10}{*}{ Avena fatua $(30 \mathrm{~cm})$} & Ranunculus spp. $(30 \mathrm{~cm})$ & Agrostis spp. $(30 \mathrm{~cm})^{2}$ \\
\hline & Sonchus spp. $(15 \mathrm{~cm})$ & Prunella spp. $(15 \mathrm{~cm})^{2}$ \\
\hline & Xanthium pensylvanicum $(30 \mathrm{~cm})$ & Achillea millefolium $(7 \mathrm{~cm})^{2}$ \\
\hline & Digitaria spp. $(30 \mathrm{~cm})$ & Dactylis glomerata $(15 \mathrm{~cm})^{2}$ \\
\hline & Polygonum aviculare $(15 \mathrm{~cm})$ & Brachiaria spp. $(15 \mathrm{~cm})^{2}$ \\
\hline & Alopecurus carolinianus $(30 \mathrm{~cm})$ & Festuca spp. $(7 \mathrm{~cm})^{2}$ \\
\hline & Chenopodium album $(30 \mathrm{~cm})$ & Hypochaeris spp. $(15 \mathrm{~cm})^{2}$ \\
\hline & Bidens pilosa $(15 \mathrm{~cm})$ & Brachiaria decumbens $(30 \mathrm{~cm})^{2}$ \\
\hline & Amaranthus spp. $(30 \mathrm{~cm})$ & \\
\hline & Panicum spp. $(30 \mathrm{~cm})$ & \\
\hline
\end{tabular}

${ }^{1}$ Maximum weeds height at which glyphosate should be applied.

${ }^{2}$ Perennials. 
weeds, and their maximum height at which they should be sprayed.

As indicated before exist different susceptibility to glyphosate according to the brush weed or tree. However this product must be applied when plants are actively growing, after full leaves expansion. The higher recommended rate should be used for larger plants and for dense areas of growth. Due to its polar movement towards more active sinks in plants, normally best results are obtained when application is made in late summer or fall after fruit formation. When brush weeds have been moved or tilled or trees have been cut, do not apply glyphosate until regrowth have reached at least 1-m of height. If these plants are at high moisture content and are flowering best results are obtained. As mentioned, glyphosate can need a partner to effectively control some of this brush or woody trees. Also repeated treatments may be necessary to control plants regenerating from underground parts.

When dealing with deciduous trees (e.x. Nothofagus spp.) or brush (e.x. Rubus spp., Rosa moschata), our experience indicate that glyphosate application for their control in site preparation (reforestation) must be performed before senescence and leaf drops, which occurs during the winter, when low temperatures prevail. In general, reduced glyphosate efficacy may result if treatment is made following a frost.

Application technique, volume and water quality. In the control of woody species in site preparation (reforestation), roots represent the main target. Because glyphosate will translocate in both the phloem and xylem the quantity of the herbicide translocated in the phloem will depend on the application rate and the distance from the receptor area (the foliage where glyphosate was deposit), to the strongest sink (most of cases the roots). The longer of this distance, the more glyphosate will move and concentrate in the youngest aerial shoots, while the toxic effect to the roots will be minimum (LundHoie, 1980). Effective control of brush species will therefore be dependent not only on its height, but also on the applications technique. Thus, when spraying with an aircraft like a helicopter, most of the spray will reach and depositate in the upper half of the crown, with only a small volume able to penetrate to the lower part of the crown. Ground-based application equipments results in the opposite effect, with most of the spray deposited on the lower part of the crown, therefore a shorter path to the roots and consequently, greater effectiveness. This could explain why when using aircraft, glyphosate rate should be increased, and according to Lund-Hoie (1980) about $50 \%$ higher rate of glyphosate is required to control brush and trees its aircraft or helicopter if used than when using ground equipments.
Relatively low water volume (12 to $40 \mathrm{~L} \mathrm{ha}^{-1}$ ) are used when aerial application equipment are utilized to spray glyphosate in forest site preparation (reforestation). To avoid drift is a must under this application conditions. Therefore glyphosate should not be applied during air mass inversions and when winds are gusty. Also, buffer zones must be maintained to avoid damage to sensible crops and to contaminate any body of water. For this reason drift control additive may be used. If land is plane, other equipment as a mist blower can be used.

Spray volume is a key factor to obtain glyphosate potential efficacy. As the volume increased the proportion of the surfactant (that the formulated glyphosate carry) in the mixture water-glyphosate decreased. If application water contains suspended colloids or ions in solutions (hard water) glyphosate efficacy can be drastically decreased. In the first case glyphosate would bind or be adsorbed by organic colloids and in the second case glyphosate can react with ions in solution forming an insoluble complex by quelation. Thus, Riesk et al. (1974) showed a reduction of 80 to $90 \%$ of toxicity of glyphosate in corn plants $\left(1.14 \mathrm{~kg}\right.$ ia ha $\left.{ }^{-1}\right)$ if the spray water contained $1 \%$ of montmorillonite or organic matter in the spray tank. Also, Pulver and Romero (1976) showed that adding 20 $\mathrm{mg}$ of soil to the solution (equivalent to $21 \%$ of clay), glyphosate effectively decreased by $15 \%$ on Cyperus rotundus. However, the rate of glyphosate used can overcome the effect of "dirty" spray water, as can be seen in Table 6 (Kogan and Correa, 2000).

Table 6. Effect of two rate of glyphosate with different concentration of soil in the spray solution (equivalent to $200 \mathrm{~L} \mathrm{ha}^{-1}$ ) on Cyperus esculentus (48 days after herbicide application) (adapted from Kogan and Correa, 2000).

\begin{tabular}{|c|c|c|c|}
\hline \multicolumn{2}{|c|}{ Treatments } & \multirow{2}{*}{$\begin{array}{c}\text { Foliar } \\
\text { damage }\end{array}$} & \multirow{2}{*}{$\begin{array}{l}\text { Foliar fresh } \\
\text { weight }\end{array}$} \\
\hline Glyphosate & Soil & & \\
\hline kg ai ha-1 & $\mathrm{mg} \mathrm{kg}^{-1}$ & $\%$ & g plant ${ }^{-1}$ \\
\hline 0 & 0 & $0 \mathrm{e} *$ & $99.4 \mathrm{a}$ \\
\hline 1.08 & 0 & $50 \mathrm{~b}$ & $56.2 \mathrm{~cd}$ \\
\hline 1.08 & 3270 & $55 \mathrm{~b}$ & $54.0 \mathrm{~cd}$ \\
\hline 1.08 & 6540 & $60 \mathrm{~b}$ & $78.2 \mathrm{ab}$ \\
\hline 1.08 & 9800 & $25 \mathrm{~cd}$ & $90.2 \mathrm{ab}$ \\
\hline 1.08 & 13080 & $36 \mathrm{c}$ & $82.0 \mathrm{ab}$ \\
\hline 2.16 & 0 & $72 a$ & $41.2 \mathrm{~d}$ \\
\hline 2.16 & 3270 & $86 a$ & $36.8 \mathrm{~d}$ \\
\hline 2.16 & 6540 & $81 \mathrm{a}$ & $42.2 d$ \\
\hline 2.16 & 9800 & $85 a$ & $40.6 \mathrm{~d}$ \\
\hline 2.16 & 13080 & $77 \mathrm{a}$ & $43.8 \mathrm{~d}$ \\
\hline
\end{tabular}

${ }^{*}$ Means of a given column followed by the same letter are not significantly different $(\mathrm{P} \leq 0.05)$ according to Tukey-Kramer multiple comparison test. 
Glyphosate behaves as a "zwiterion" which means it presents positive and negative charges in the molecule or functional acid and base groups. According to Franz (1985) glyphosate can show different $\mathrm{pKa}$ values, depending on solution $\mathrm{pH}\left(\mathrm{pK}_{1}=0.78 ; \mathrm{pK}_{2}=2.27 ; \mathrm{pK}_{3}\right.$ $=5.56$ and $\mathrm{pK}_{4}=10.5$ ). Because of glyphosate can react with ions in solution forming a complex glyphosate-ion (quelate).

To know the concentration and type of dissolved ions in the spraying water is fundamental to understand the potential effect of them on glyphosate phytotoxicity. Several factors can determine whether or not dissolved ions in the spray solution affect glyphosate efficacy. Thus, ion types, ion concentration, glyphosate rate and spray volume are very important. In general it is well accepted that trivalent ions $\left(\mathrm{Al}^{+3}, \mathrm{Fe}^{+3}\right)$ are more antagonic than the bivalent $\left(\mathrm{Ca}^{+2}, \mathrm{Mg}^{+2}\right)$ and these more than the monovalents $\left(\mathrm{Na}^{+}, \mathrm{K}^{+}\right)$.

Some selected research reports will be used to briefly discuss the interactions between factors that can explain glyphosate antagonism with dissolved ions in the spray water. The work of Buhler and Burnside (1983) clearly shows that $\mathrm{Ca}^{+2}$ concentration in the spray solution can produce no effect, antagonic effect o no additional effect, even though $\mathrm{Ca}^{+2}$ concentration is drastically increases (Table 7).

Evidences for the interaction spray volume and $\mathrm{Ca}^{+2}$ concentrations are presented by Sandberg et al. (1978). They showed $\mathrm{Ca}^{+2}$ did not reduce glyphosate phytotoxicity to Ipomoea sp. when spray volume was equal or less than $190 \mathrm{~L} \mathrm{ha}^{-1}$ and $\mathrm{Ca}^{+2}$ concentration was equal or less than $0.02 \mathrm{MCaCl}_{2}\left(800 \mathrm{mg} \mathrm{kg}^{-1} \mathrm{Ca}^{+2}\right.$, which means 2000 $\mathrm{mg} \mathrm{CaCO}{ }_{3}$ water hardness equivalent). There is a clear relationship between spray volume, $\mathrm{Ca}^{+2}$ concentration on antagonistic effect on glyphosate (Table 8).

Table 7. Effect of $\mathrm{Ca}^{+2}$ concentration on glyphosate phytotoxicity to Avena sativa (rate $=0.4 \mathrm{~kg} \mathrm{ha}^{-1}$; spray volume $\left.=190 \mathrm{~L} \mathrm{ha}^{-1}\right)($ adapted from Buhler and Burnside, 1983).

\begin{tabular}{cc}
\hline $\mathbf{m M} \mathbf{C a C l}_{\mathbf{2}}$ & Effect on glyphosate \\
\hline 0 & No effect \\
1 & No effect \\
2 & No effect \\
4 & Antagonism \\
6 & Antagonism \\
8 & Antagonism \\
16 & No additional antagonism \\
32 & No additional antagonism \\
64 & No additional antagonism \\
128 & No additional antagonism \\
\hline
\end{tabular}

Another interesting interaction is the relation between antagonistic effect of ion concentrations and glyphosate rate. In an unpublished work (Figure 1) (Martínez and Kogan) in which is possible to see that $\mathrm{Al}^{+3}$ was antagonic to glyphosate when its rate was only $180 \mathrm{~g}$ ai ha- $\mathrm{h}^{-1}$. At that rate the antagonic effect was directly proportional to $\mathrm{Al}^{+3}$ concentrations. However as glyphosate rate increased to $270 \mathrm{~g}$ ai ha ${ }^{-1}, \mathrm{Al}^{+3}$ antagonism was only detectable with the highest ion concentration $\left(120 \mathrm{mg} \mathrm{kg}^{-1}\right)$. No antagonism was produced by $\mathrm{Al}^{+3}$ when glyphosate rate was $450 \mathrm{~g}$ ai ha ${ }^{-1}$, independent of ion concentration.

The examples given are just a small portion of the numerous references that can be found in the literature revealing interactions between glyphosate rates, ion concentrations and spray water volume. Also the test plant used can also affect the obtained result. Even thought it should be considered that in real circumstances, at field level, hard water may content the most diverse proportions of different ions in solution. For that reason it is not enough to express water hardness as $\mathrm{mg} \mathrm{kg}^{-1} \mathrm{CaCO}_{3}$ equivalent, because in that way we do not know the exact proportion of the main ions present. Even though, mainly $\mathrm{Ca}^{+2}$ and $\mathrm{Mg}^{+2}$ are the most considered ions to calculate waters hardness. Two different water samples could have the same hardness expressed as $\mathrm{mg} \mathrm{kg}^{-1} \mathrm{CaCO}_{3}$, but they can markedly differ in type and proportions if ions. Besides the criteria used to define and establish different level of water hardness was not developed thinking in agricultural pesticide applications. Thus, hard water not always will be antagonistic to glyphosate. For all these reasons if one suspect that water hardness could affect glyphosate, a water chemical analysis should be made looking the different ions present, and their concentrations, under these circumstances, it should not be forgotten that using lower spray volume (no $>150 \mathrm{~L} \mathrm{ha}^{-1}$ ) most of factors that can affect glyphosate efficacy diminish their real impact.

Glyphosate rainfastness. During the period between spraying and foliar absorption of a lethal dose by the plant, glyphosate is vulnerable to removal by rain. In wet period, the "wash off" of glyphosate from the leaves will reduce the performance of the mixture, because of their relatively slow uptake. Woody species are more vulnerable in this respect than grasses or other herbaceous species. Even though rate of foliar uptake will depends on specific species morphology mainly on leaf characteristics, physical and chemical. The type of spraying equipment used will also influence glyphosate rainfastness. Mix blower, which deposit compound in both sides of the leaves, can require a shorter period with no rain after application.

Several workers have reported that a $6-8 \mathrm{~h}$ rainfree period is required for penetration of sufficient active ingredient to produce acceptable performance of 
Table 8. Effect of the interaction $\mathrm{Ca}^{+2}$ and spraying water volume to Ipomoea spp. growth under greenhouse conditions, $30 \mathrm{~d}$ after glyphosate $1.68 \mathrm{~kg} \mathrm{ha}^{-1}$ application (adapted from Sandberg et al., 1978).

\begin{tabular}{|c|c|c|c|c|c|c|}
\hline \multirow[b]{2}{*}{ Volume } & \multicolumn{6}{|c|}{$\mathrm{CaCl}_{2}$} \\
\hline & 0 & 0.0025 & 0.005 & 0.01 & 0.02 & 0.04 \\
\hline $\mathrm{L} \mathrm{ha}^{-1}$ & & & 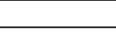 & & & \\
\hline 130 & $3.0 \mathrm{a}$ & $7.3 \mathrm{a}$ & $10.0 \mathrm{ab}$ & $6.3 \mathrm{a}$ & $16.3 \mathrm{ac}$ & $30.3 \mathrm{ce}$ \\
\hline 190 & 7.9a & $8.1 \mathrm{a}$ & $8.0 \mathrm{a}$ & $18.6 \mathrm{ad}$ & $8.6 \mathrm{e}$ & 41.6de \\
\hline 375 & $11.0 \mathrm{ab}$ & $33.3 \mathrm{ce}$ & $39.5 \mathrm{ce}$ & $46.3 \mathrm{e}$ & $43.7 \mathrm{e}$ & $44.4 \mathrm{e}$ \\
\hline 750 & $3.0 \mathrm{ce}$ & $51.3 \mathrm{e}$ & $44.1 \mathrm{a}$ & $31.8 \mathrm{e}$ & $48.9 \mathrm{e}$ & $44.7 \mathrm{e}$ \\
\hline
\end{tabular}

Different letters indicate significant differences.

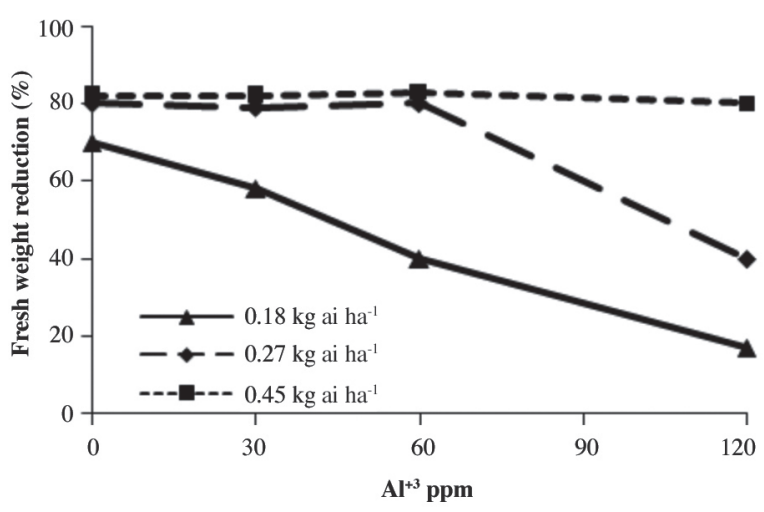

Figure 1. Antagonistic effect of $\mathrm{Al}^{+3}$ concentration on different glyphosate rates, measured as reduction of Avena sativa fresh weight (Martínez and Kogan, unpublished data).

glyphosate (Behrens and Elakkad, 1976; Coupland and Caseley, 1981).

It is likely any plant or environmental factor that slows entry of glyphosate into the plant would prolong the rainfastness. Manipulation of formulations may reduce the risk of glyphosate wash off from the foliage. Also higher concentration of glyphosate as a consequence of low volume application could also diminish the effect of rain after application, may due to enhancement of glyphosate foliar rate uptake.

Intrinsic plant tolerance to glyphosate can also determine its rainfastness requirement. Thus, a $4 \mathrm{~h}$ rainfastness was required to control johnsongrass (Sorghum halepense) from seeds, with glyphosate isopropylamine salt at rate of $680 \mathrm{~g}$ ai ha-1 ${ }^{-1}$, but lowering rate to $340 \mathrm{~g}$ ai ha-1 the adverse effect of rain was much more drastic. Maybe because $4 \mathrm{~h}$ were not enough to allow the entry of a lethal rate of glyphosate (Bryson, 1988). In a more tolerant herbaceous weed like purple nutsedge (Cyperus rotundus), it was required $12 \mathrm{~h}$ of rain free-period for glyphosate isopropylamine salt at $2.16 \mathrm{~kg}$ ai ha ${ }^{-1}$, to effectively decrease tuber sprouting capacity, and $24 \mathrm{~h}$ at a rate of $1.44 \mathrm{~kg}$ ai ha ${ }^{-1}$ (Kogan, 2000). Even though Bariuan et al. (1999) indicate that a rain free period of $72 \mathrm{~h}$ prevented loss of glyphosate activity on $C$. rotundus.

Glyphosate formulations can be differently affected by rain after their application. Jakelaitis et al. (2001) showed it was required a rainfastness of 4 and $6 \mathrm{~h}$ to control Digitaria horizontalis when were treated with glyphosate isopropylamine (IPA salt; Roundup Transorb), glyphosate potassium (K-salt) or glyphosate trimethylsulfonium salts (TMS salt). However the conventional glyphosate formulation and the ammonium salt (AM salt), were the most affected because of the rain (Jakelaitis et al., 2001). In a different grass, Brachiaria decumbens, it was required a rainfastness of 8,11 and $12 \mathrm{~h}$ when glyphosate was applied as K-salt, IPA salt, and AM salt, respectively (Verlag et al., 2003). Increasing the rate from 1004 to 2160 $\mathrm{g}$ ai $\cdot \mathrm{ha}^{-1}$ they were able to shorten the rainfastness. On the other hand, Jakelaitis et al. (2003) spraying a lower rate, $720 \mathrm{~g}$ ai ha ${ }^{-1}$, found a rainfastness of 2, 4 and $6 \mathrm{~h}$ for IPA salt, K-salt and AM salt, respectively.

It looks like not the salt type, but the formulated product (type and concentration of coadjuvants) can account for the different rainfastness requirements for the several commercial glyphosates.

When dealing with woody species glyphosate rainfastness could be prolonged. Thus, Lund-Hoie (1980) found an absorption period of almost $2 \mathrm{wk}$ of glyphosate for Fraxinus excelsior, and for Picea abies, about one half of this (Lund-Hoie, 1976). Comparing rainfastness of glyphosate with triclopyr and clopyralid (Table 9), it is possible to see that $15 \mathrm{~min}$ of rain free period was enough for Pyridine herbicides to achieve 92 and $100 \%$ of Prosopis gladulosa control, but glyphosate efficacy was very variable and required no rain after application to get similar level of control.

Dew effect on glyphosate efficacy. Most field applications of glyphosate in forestry conditions in Chile, start early in the morning to avoid windy conditions that develop later during the day. Under these conditions, the presence of dew on weeds during herbicide application has caused 
Table 9. Prosopis gladulosa control (\%) with glyphosate, triclopyr and clopyralid at $0.8 \mathrm{~kg}$ ai ha $\mathrm{ha}^{-1}$ under $2.5 \mathrm{~cm}$ of simulated rain with different rainfastness periods (adapted from Bovey et al., 1990).

\begin{tabular}{lcc}
\hline Herbicide & Rainfastness & Control \\
\hline min & $0^{1}$ & $\%$ \\
15 & 37 \\
30 & 54 \\
60 & 39 \\
Glyphosate & 240 & 11 \\
Triclopyr & Without rain & 57 \\
& 0 & 95 \\
& 15 & 46 \\
30 & 92 \\
60 & 84 \\
& 240 & 97 \\
& Without rain & 96 \\
0 & 62 \\
15 & 100 \\
& 30 & 100 \\
60 & 100 \\
& 240 & 100 \\
& Without rain & 100 \\
\hline & &
\end{tabular}

${ }^{1}$ Rain right after application.

some concern among herbicide applicators. Dew defined as the presence of free water on plant foliage (Slatyer, 1968) could affect foliar uptake and therefore efficacy of foliar-applied herbicides, mainly those of height water solubility, like glyphosate.

Dew before spraying has tended to be regarded as undesirable by many forest managers and contractors, but the limited experimentation on this topic does not fully support this view (Caseley and Coupland, 1985).

Sometimes, glyphosate application is not performed when dew is present, delaying application until the foliage dries (Kudsk et al., 1988). The presence of dew at application is believed to increase or decrease foliar herbicide efficacy (Caseley, 1989). Herbicide runoff and herbicide dilution could explain the negative effect of dew (Muro, 1991). By contrast, dew can increase the total area of herbicide interception and reduce the impact of large drops on foliage surfaces, avoiding their loss from the leaves (Johnstone, 1973). At the same time, the presence of dew results in hydration of the cuticle and may play an important role favoring foliar uptake (Caseley, 1989).

The effect of dew on herbicide activity is not thoroughly understood due to limited research, where dew has not been quantified. Thus, measurement taken on a given day showed that some plants were able to retain an average of $195 \mathrm{~mL}$ water $\mathrm{g}^{-1}$ fresh weight of foliage, which could represent from 36 to $90 \%$ of their fresh weight, and others retained an average of $76 \mathrm{~mL}$ water $\mathrm{g}^{-1}$ fresh weight of foliage, which varied from 12 to $35 \%$ of their fresh weight. The natural variability we observed makes results on effect of dew on herbicide performance difficult to explain. Because of the general lack of empirical knowledge about the effect of dew, an experiment was conducted to study the effect of known dew levels on glyphosate efficacy applied with different spray volumes (Kogan and Zúñiga, 2001). Results showed that glyphosate phytotoxicity decreased with increasing carrier volume for plants without or with dew (Table 10; Figure 2). Several reports indicate that glyphosate efficacy is greater when applied in low rather than in high volumes (Sandberg et al., 1978; Rambakudzibga 1989; Liu-Shuhua et al., 1996). Nevertheless, other reports have shown no effect of carrier volume on glyphosate phytotoxicity (Messersmith et al., 1992; Willard et al., 1998).

The effect of dew level on glyphosate efficacy can depend on spray volume. Thus, glyphosate activity at low and medium volumes (150 and $300 \mathrm{~L} \mathrm{ha}^{-1}$ ) was not affected by dew level. Decrease of plant fresh weight of treated plants with glyphosate at 150 and $300 \mathrm{~L} \mathrm{ha}^{-1}$ was statistically equal, regardless of dew level. Decrease in glyphosate efficacy was seen only when applied in high spray volume $\left(450 \mathrm{~L} \mathrm{ha}^{-1}\right)$. This effect is more obvious from analyzing the growth of the fourth leaf of the treated plants (Table 10 and Figure 2).

The presence of dew on plant foliage is conducive to a fully hydrated cuticle, and it aids water-soluble compounds as glyphosate to remain in solution (Caseley and Coupland, 1985). Thus, glyphosate will remain in solution for a longer period of time before drying, when leaves are covered with dew and a low spray volume is used, which will not cause runoff. These conditions could

Table 10. Effect of volume and dew levels on glyphosate $\left(0.54 \mathrm{~kg} \mathrm{ai} \mathrm{ha}^{-1}\right)$ efficacy on oat plant fresh weight per pot, $15 \mathrm{~d}$ after treatments (adapted from Kogan and Zúñiga, 2001).

\begin{tabular}{lccc}
\hline \multirow{2}{*}{$\begin{array}{l}\text { Spray } \\
\text { volume }\end{array}$} & \multicolumn{3}{c}{ Dew levels (\%) } \\
\cline { 2 - 4 } $\mathrm{L} \cdot \mathrm{ha}^{-1}$ & \multicolumn{5}{c}{$\mathbf{5 0}$} & $\mathbf{1 0 0}$ \\
\cline { 2 - 4 } 150 & $0.52 \mathrm{~cd}$ & $0.46 \mathrm{~d}$ & $0.48 \mathrm{~d}$ \\
300 & $0.74 \mathrm{c}$ & $0.50 \mathrm{~cd}$ & $0.52 \mathrm{~cd}$ \\
450 & $1.48 \mathrm{a}$ & $1.49 \mathrm{a}$ & $1.72 \mathrm{a}$ \\
\hline
\end{tabular}

"Untreated oat check plant average fresh weight was $4.2 \mathrm{~g}$. Different letters indicate statistical differences, Duncan $(\mathrm{P}<0.05)$. 


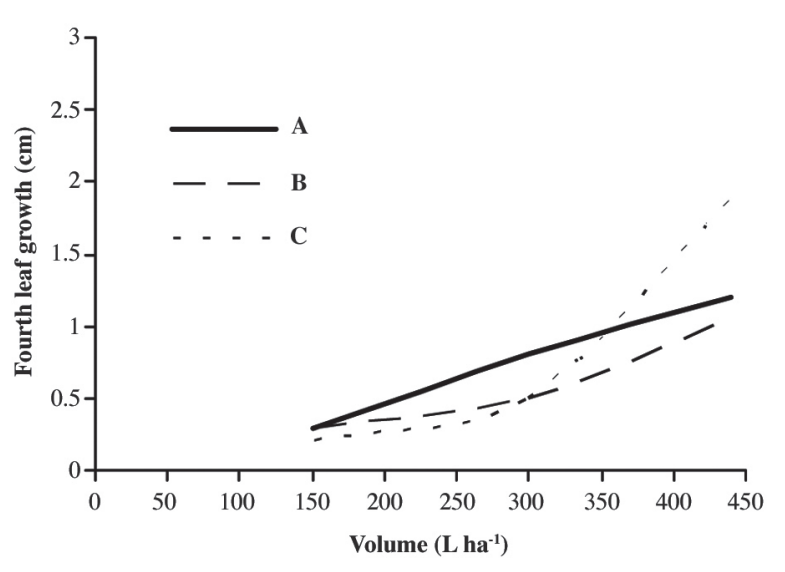

Figure 2. Effect of dew level and spray volume on glyphosate $(0.54 \mathrm{~kg}$ ai ha-1) efficacy, measured $15 \mathrm{~d}$ after application as increase in oat fourth leaf growth. A) Plants with no dew, B) plants with $50 \%$ dew $(239.7$ $\mu \mathbf{L}$ water $\mathbf{~}^{-1}$ fresh weight of foliage), and C) plants with $100 \%$ dew $\left(479.5 \mu \mathrm{L}\right.$ water $\mathrm{g}^{-1}$ fresh weight of foliage) (adapted from Kogan and Zuñiga, 2001).

enhance foliar uptake. However, Merrit (1982) reported an enhancement of glyphosate foliar absorption by moisture and concentrated deposit. Consequently, a fully hydrated cuticle should support foliar uptake of mainly water-soluble herbicides, which are believed to enter a hydrophilic pathway. Accordingly, the enhanced uptake of glyphosate applied with a low spray volume in leaves with heavy dew can compensate for the dilution of the herbicide deposit.

The majority of plants have leaf surfaces with a high contact angle hysteresis, and reflection of spray drops is likely. The major exception is when drops hit a surface that is already covered with a film of water (Scotland, 1960), which could occur for sprays soon after a rain or with heavy dew. High spray volumes used during heavy dew conditions could exceed the water-holding capacity, and runoff could occur. Thus, heavy dew before a high volume glyphosate application would lead to decreased performance.

Caseley et al. (1975) reported that a heavy dew (554 to $864 \mu \mathrm{L} \mathrm{g}^{-1}$ fresh wt of foliage) delayed drying of the glyphosate spray deposit by 3 to $3.5 \mathrm{~h}$ on quackgrass (Elytrigia repens) foliage, and herbicide performance was not diminished following application to wet compared to dry leaves. In contrast, they showed that the highest water load significantly increased the reduction of foliage fresh weight, believing that glyphosate uptake was enhanced. It must be mentioned that these authors used a normal (low) spray volume of $230 \mathrm{~L} \mathrm{ha}^{-1}$.

By contrast, Behrens (1977) indicated a heavy dew deposit at the time of herbicide application resulted in some runoff and diminished the performance of glyphosate. In this case, it should be noted that plants were nearly saturated with dew, approaching runoff when herbicide was applied. These conditions were very much like the heavy dew level applied to the oat plants in the experiment reported by Kogan and Zuñiga (2001). Kudsk et al. (1988) showed that the effect of glyphosate on barley (Hordeum vulgare L. cv. Jenny) was considerably greater on plants with natural dew, independent of the herbicide applied in a volume 130 or $278 \mathrm{~L} \mathrm{ha}^{-1}$, but in experiments with simulated dew, light or heavy dew did not influence glyphosate applied in a volume of 307 or $149 \mathrm{~L} \mathrm{ha}^{-1}$. No rational explanation was offered by the authors for those contradictory results. In contrast to the results with barley, heavy dew on white mustard (Sinapsis alba L.) foliage reduced glyphosate efficacy applied at a high volume (307 $\mathrm{L} \mathrm{ha}^{-1}$ ).

According to Behrens (1977), dew could increase or decrease herbicidal activity to different degrees depending on the specific herbicide, herbicide rate, and plant species involved. It can be said that glyphosate efficacy can be reduced when applied in high volume (450 $\left.\mathrm{L} \mathrm{ha}^{-1}\right)$ with heavy dew, probably attributable to spray runoff. As a summary, it could be said that the limited knowledge on this topic, as well as all factors involved in glyphosate foliar uptake, does not permit oneself to make universal recommendations, but it can concluded that heavy dew level and high spray volume appear to reduce glyphosate efficacy. Considering that, low volume spray of glyphosate will directly increase herbicide performance and will reduce the potential for reduced efficacy from dew. In normal field conditions, dew would be mostly moderate with little effect on glyphosate applied relatively low volume $\left(\leq 200 \mathrm{~L} \mathrm{ha}^{-1}\right)$.

Use of extra coadjuvants with formulated glyphosate. Materials which for some reason are not included in the manufacturer's formulation and are added to the spray just before using are considered additives or adjuvants. Some are similar or identical the formulation ingredients which are used by the chemical companies, for example surfactant, whereas others, such as ammonium salts, are rarely found in commercial formulations. Others herbicides may be used as an additive, to widen spectrum of weed control. In Chile authors have had excellent results with mixtures of glyphosate $(0.72-1.08 \mathrm{~kg}$ ia ha-1) with oxyfluorfen $\left(54 \mathrm{~g} \mathrm{ha}^{-1}\right)$ or with flumioxazin $\left(25 \mathrm{~g} \mathrm{ha}^{-1}\right)$. Both at very low rate (54 and $25 \mathrm{~g} \mathrm{ha}^{-1}$, respectively) offered a quick burn down of many weeds that are relatively tolerant to glyphosate (e.x. Malva spp., Modiola caroliniana, Urtica spp., Pitrea cuneo-ovata, Trifolium spp., Euphorbia spp.).

Addition of extra surfactant to formulated 
glyphosate is been a much explored research area. Many papers have been produced with the most variable responses (Nalewaja and Matysiak, 1993; Miller et al., 1998; Feng et al., 1999; Sharma and Singh, 1999; 2000; Sharma et al., 2001; Belcher et al., 2004; Singh and Singh, 2008; Martins et al., 2009) from increasing, decreasing and no effect of adding extra surfactant. Most of these reports of adding surfactant or other adjuvant (e.g. ammonium sulfate) to formulated glyphosate have been performed in annual and or perennial monocots and dicot herbaceous weeds. Because weed species can differ in terms of leaf lipophilicity and this can affect wetability and foliar absorption, the addition of surfactant to formulated glyphosate could enhance herbicide efficacy in one weed but not in others (Table 11). No much research is being conducted on the effect of adding surfactant to formulated glyphosate applied to brush and trees. Because a higher glyphosate rate is used normally to control these weeds, the extra surfactant effect can be unlikely, mainly if relatively low spray volume are utilized (e.g. aircraft or helicopter application). Nevertheless addition of extra surfactant often improves the effect of commercial glyphosate, particularly when low rates $\left(\leq 0.48 \mathrm{~kg}\right.$ ai ha $\left.{ }^{-1}\right)$, relatively high spray volume $(>300$ $\mathrm{L} \mathrm{ha}^{-1}$ ) are applied to relatively tolerant weed species. Glyphosate (commercial) is used for many and varied purposes and dose may vary from 0.36 to $3 \mathrm{~kg}$ ai ha-1, or more, and spray volume from 15 to $500 \mathrm{~L} \mathrm{ha}^{-1}$. The ratio of surfactant to herbicide in the traditional commercial glyphosate (Roundup ${ }^{\circledR}$ ) is fixed so that the use of single formulation for such diverse treatments must involve compromise. It seems likely, the surfactant level in Roundup is being intended for application of about $1.5 \mathrm{~kg}$ ai ha- $\mathrm{ha}^{-1}$ herbicide in 200-

Table 11. Effect of organosiliconate surfactant Silwet L-77 on the required glyphosate trimesium rate $\left(\mathrm{g} \mathrm{ha}^{-1}\right)$ to achieve $90 \%$ of control on different herbaceous weed species (adapted from Baylis and Hant, 1993).

\begin{tabular}{lccc}
\hline & \multicolumn{3}{c}{ Silwet L-77 concentration $(\% \mathbf{v} / \mathbf{v})$} \\
\cline { 2 - 4 } Species & $\mathbf{0}$ & $\mathbf{0 . 1 2 5}$ & $\mathbf{0 . 5}$ \\
\cline { 2 - 4 } g ha $^{-1}$ & \\
\cline { 2 - 4 } Chenopodium album & 712 & 625 & 722 \\
Conyza canadensis ${ }^{1}$ & 709 & $298^{*}$ & $169^{*}$ \\
Polygonum aviculare & 711 & 802 & $2080^{*}$ \\
Eleusine indica & 725 & 923 & $1338^{*}$ \\
Digitaria sanguinalis & 361 & 375 & 406 \\
Lolium perenne & 692 & 577 & $494^{*}$ \\
Cyperus rotundus & 1037 & 791 & $748^{*}$ \\
\hline
\end{tabular}

*Indicates significant difference respect Silwet L-77 dose.

${ }^{1}$ Only $60 \%$ control in this case.
$250 \mathrm{~L} \mathrm{ha}^{-1}$ and it will be inadequate when less amount of acid equivalent is applied in the same spray volume. Conversely, when higher doses are applied in very low volume, the surfactant concentration may be too high.

It is well known that some surfactant especially organosiliconates can reduce glyphosate rainfastness because initial foliar absorption rate may be increased. For this reason their use is recommended as an "insurance" when glyphosate is applied mainly in reforestation site preparation when rainfall can suddenly occur after application. Different commercial formulation can present rainfastness from 2 to more than $12 \mathrm{~h}$ in the case of some herbaceous weeds.

Glyphosate is a weak acid, sold as the isopropylamine salt, ammonium, potassium or trimethylsulfonium salt. Several commercial products containing these salts, from different companies, are in the market. Besides of differing in their equivalent acid content they can also differ in surfactant type and amount in their formulations. Therefore there is a clear necessity for more research in this field to find out if they really can shorten glyphosate rainfastness, and/or enhance its efficacy when they are applied to control different brush and tree weeds.

\section{RESUMEN}

Uso de glifosato en plantaciones forestales. Bajo las condiciones chilenas la falta de control de malezas al establecimiento de los árboles resulta en un promedio de al menos $60 \%$ menos acumulación de biomasa durante el primer año de crecimiento de pino radiata o eucalipto, y glifosato ofrece una serie de ventajas en el manejo de malezas forestales debido a su actividad en ambos grupos de malezas herbáceas, monocotiledóneas y dicotiledóneas, así como anuales, bianuales y perennes. Además, su eficacia en la vegetación leñosa indeseable hace al glifosato un herbicida muy importante que puede ser aplicado para controlar malezas herbáceas y leñosas en pre-plantación y durante el segundo o tercer año de crecimiento de los árboles como aplicaciones en franja. El objetivo de esta revisión es discutir los principales usos de glifosato en reforestación a lo largo del mundo, durante los primeros 2 años después del establecimiento de los árboles, como aplicación al voleo por sobre los árboles en el bosque y los factores más importantes que pudieron afectar la eficacia de glifosato como un herbicida forestal, como estado del crecimiento de maleza, técnica de aplicación, volumen y calidad del agua, resistencia al lavado por lluvia, efecto rocío y el uso de adyuvantes extra con glifosato formulado.

Palabras clave: pino, eucalipto, resistencia al lavado por lluvia, plantas leñosas. 


\section{LITERATURE CITED}

Balneaves, J., and D. Henley. 1992. Seven years growth response of radiate pine to area of herbaceous weed control. p. 262-263. Proceedings of the $45^{\text {th }}$ New Zealand Plant Protection Conference, Wellington, New Zealand. 11-13 August. New Zealand Plant Protection Society Inc., Rotorua, New Zealand.

Bariuan, J., K. Reddy, and G. Wills. 1999. Glyphosate injuring, rainfastness, absorption and translocation in purple nut sedge (Cyperus rotundus). Weed Technology 13:112-119.

Baylis, A., and A. Hant. 1993. Varying responses among weed species to glyphosate trimesium in the presence of an organonsilicone surfactant. p. 1331-1336. Proceedings of Brighton Crop Protection ConferenceWeeds. 22-25 November. United Kingdom.

Behrens, R. 1977. Influence of dew on the phytotoxicity of foliarly applied herbicides. p. 116. Proceedings of North Central Weed Control Conference, Garden City, New York.

Behrens, R., and M. Elakkad. 1976. Influence of rainfall on phytotoxicity of foliarly applied herbicide. p. 141. Proceedings of the North Central Weed Control Conference, Garden City, New York.

Belcher, S., J. Sanders, D. Stephenson, W. Faircloth, and M. Patterson. 2004. Field performance of glyphosate as influenced by selected adjuvants and low-volume, air-assisted sprayers. Weed Technology 18:458-463.

Bovey, W., E. Meyer, and G. Whisenant. 1990. Effect of simulated rainfall on herbicide performance in Huisache (Acacia farnesiana) and Honey Mesquite (Prosopis grlandulos). Weed Technology 4:26-30.

Bryson, C. 1988. Effects of rainfall on foliar herbicides applied to seedling johnsongrass (Sorghum halepense). Weed Technology 2:153-158.

Buhler, D., and C. Burnside. 1983. Effect of water quality, carrier volume and acid on glyphosate phytotoxicity. Weed Science 31:163-169.

Caseley, J. 1989. Variation in foliar pesticide performance attributable to humidity, dew and rain effects. Aspects of Applied Biology 21:215-225.

Caseley, J., and D. Coupland. 1985. Environmental and plant factors affecting glyphosate uptake, movement and activity. p. 92-123. In Grossbard, E., and D. Atkinson (eds.) The herbicide glyphosate. Butterworth, London, UK.

Caseley, J., D. Coupland, and R. Simmons. 1975. The effect of precipitation on the control of Agropyron repens with glyphosate. Symposium on Status and Control of Grassweeds in Europe. Proceedings of European Weed Research Society, Paris 1:124-130.
Coupland, D., and J. Caseley. 1981. Environmental influences on the effects of glyphosate on Agropyron repens. p. 109-114. Proceedings of the AAB Conference. Grass Weeds in Cereals in the United Kingdom, Reading, UK.

CPCR. 1987. Crop Protection Chemicals Reference. $3^{\text {rd }}$ ed. 2022 p. Chemical and Pharmaceutical Press, John Willey \& Sons Canada, Toronto, Canada.

CPCR. 2001. Crop Protection Chemicals Reference. $17^{\text {th }}$ ed. 545 p. Chemical and Pharmaceutical Press, Monaco.

Feng, P., J. Ryerse, C. Jones, and S. Sammons. 1999. Analysis of surfactant damage using microscopy and its relation to glyphosate or deuterium oxide uptake in velvetleaf (Abutilon theophrasti). Pesticide Science 55:385-386.

Franz, J. 1985. Discovery development and chemistry of glyphosate. p. 3-17. In Grossbard, E., and D. Atkinson (eds.) The herbicide glyphosate. Butterworth, London, UK.

Haig, R., J. Nolan, and F. von Althen. 1990. Summary of the Proceedings of the Hardwood Establishment and Management Symposium. Joint Report 16. Forestry Canada, Ontario Region, Canada.

Harmer, R., and G. Kerr. 1995. Creating woodland to plant tree or not? 113-128. In R. Ferris-Kaan (ed.) The ecology of woodland creation. John Willey, Chichester, UK.

Jakelaitis, A., L. Ferreira, A. da Silva, and G. Miranda. 2001. Controle de Digitaria horizontalis pelos herbicidas glyphosate, sulfosate, e glifosate potassico submetidos a diferentes intervalos de chuva após aplicacao. Planta Daninha 19:279-285.

Jakelaitis, A., A. Silva, A. da Silva, A. Machado, e G. de Freitas. 2003. Efeitos da chuva sobre a eficacia de formulacoes de glyphosate no controle de Brachiaria decumbens. Revista Ceres 50:461-469.

Johnstone, D. 1973. Spreading and retention of pesticide sprays. p. 343-386. In W. van Valkenburg (ed.) Pesticide formulations. Marcel Dekker, New York, USA.

Kogan, M. 2000. Período libre de precipitación requerido por glifosato para el control de chufa púrpura (Cyperus rotundus). (Glyphosate rainfastness requirements to purple nutsedge control (Cyperus rotundus)). Ciencia e Investigación Agraria 27:21-25.

Kogan, M., y G. Correa. 2000. Efecto de la contaminación con suelo de la solución herbicida de glifosato en el control de Cyperus esculentus (Effect of suspended soil in the application glyphosate-water mixture on Cyperus esculentus control). Ciencia e Investigación Agraria 27:181-185. 
Kogan, M., y R. Figueroa. 1997. Control de malezas herbáceas en primer y segundo año de desarrollo de Pinus radiata D. Agroanálisis Mayo-Junio:14-18.

Kogan, M., y R. Figueroa. 1999. Control químico de malezas leñosas en plantaciones de pino. Agronomía y Forestal UC 1:6-10.

Kogan, M., R. Figueroa, and H. Gilabert. 2002. Weed control intensity effects on young radiate pine growth. Plant Protection 21:253-257.

Kogan, M., and M. Zuñiga. 2001. Dew and spray volume effect on glyphosate efficacy. Weed Technology 15:590-593.

Kudsk, P., T. Olesen, K. Jensen, and E. Kirknel. 1988. The influence of dew on the activity of various herbicides. Med. Fac. Landbouww. Rijksuniv. Gent. 53/3b. p. 1289-1296.

Lund-Hoie, K. 1976. The correlation between the tolerance of Norway Spruce (Picea abies) to glyphosate (N-phosphonomethylglycine) on the uptake, distribution and metabolism of the herbicide in the spruce plants. Scientific Reports of the Agricultural University of Norway 55(21).

Lund-Hoie, K. 1980. The impact of helicopter application of glyphosate on the management of Norwegian forest plantations. p. 73-81. Proceedings of Weed Control in Forestry Conference. 1-2 April. University of Nottinham, England

Lund-Hoie, K. 1985. Efficacy of glyphosate in forest plantations. p. 328-338. In Grossbard, E., and D. Atkinson (eds.) The herbicide glyphosate. Butterworth, London, UK.

Liu-Shuhua, R., S. Campbell, H. Liu, and J. Griffith. 1996. Efficacy of glyphosate on Pupulus tremuloides as affected by droplet size and spray volume. New Zealand Journal of Forestry 26:1-2, 276-287.

Marer, J., M. Grimes, and R. Cronwell. 1995. Forest and right of way pest control. Publication 3336. 240 p. University of California, Statewide Integrated Pest Management Project, Division of Agriculture and Natural Resources.

Martins, D., C. Carbonari, M., Terra, and S. Marchi. 2009. The effect of adjuvants on glyphosate absorption and translocation in water hyacinth (Eichhornia crassipes). Planta Daninha 27:155-163.

Merrit, C. 1982. The influence of form of deposit on the phytotoxicity of MCP, paraquat and glyphosate applied as individual drops. Annals of Applied Biology 101:527-532.

Messersmith, C., K. Christianson, and K. Thorsness. 1992. Influence of glyphosate rate, application date, and spray volume on cattail control. North Dakota Farm Research 49:7-28.
Miller, D., J. Griffin, and E. Richard. 1998. Johnsongrass (Sorghum halepense) control and rainfastness with glyphosate and adjuvants. Weed Technology 12:617622.

Muro, J. 1991. Influencia del rocío y del volumen de caldo de aplicación en la eficacia de tres herbicidas de contacto. p. 271-274. Actas Reunión Sociedad Española de Malerbología, Córdoba, España.

Nalewaja, J., and R. Matysiak. 1993. Optimizing adjuvants to overcome glyphosate antagonistic salts. Weed Technology 7:337-342.

Nambiar, E. 1995. Sustained productivity of plantation: Science and practice. Bosque 16:3-8.

Nambiar, E., and R. Sand. 1993. Competition for water and nutrient in forest. Canadian Journal of Forest Research 23:1955-1968.

Newton, M., and F. Knight. 1981. Handbook of weed and insect control: chemicals for forest resources managers. 213 p. Timber Press, Beawerton, Oregon, USA.

Pulver, E., and C. Romero. 1976. Foliar absorption and translocation of glyphosate in Cyperus rotundus. Revista COMALFI 3:94-113.

Radosevich, S., E. Roncoroni, S. Conrad, and W. McHensy. 1980. Seasonal tolerance of six coniferous species to eight foliage-active herbicides. Forest Science 26:3-9.

Rambakudzibga, A. 1989. Effect of spray volume and additives on the activity of glyphosate on purple nutsedge (Cyperus rotundus L.) Zimbawue Journal of Agricultural Research 27:113-121.

Riesk, C., T. Wright, and T. Harger. 1974. Fate of glyphosate in soil. Abstracts 1974 Meeting Weed Science Society of America, USA.

Sandberg, L., W. Meggit, and D. Penner. 1978. Effect of diluent volume and calcium on glyphosate phytotoxicity. Weeds 28:477-479.

Scotland, L. 1960. Experimental results relating to the coalescence of water drops with water surface. Discussion of the Faraday Society 30:72. p. 328-338. In Grossbard, E., and D. Atkinson (eds.) The herbicide glyphosate. Butterworth, London, UK.

Sharma, S., and M. Singh. 1999. Effect of two adjuvant types on the distribution of ${ }^{14} \mathrm{C}$-glyphosate applied to model weed species. p. 729-734. Proceedings of 1999 BCPC Conference-Weeds, Brighton, UK.

Sharma, S., and M. Singh. 2000. Optimizing foliar activity of glyphosate on Bidens frondosa and Panicum maximum with different adjuvant types. Weed Research 40:523-533. 
Sharma, S., M. Singh, and R. Brlansky. 2001. Adjuvant affects cuticular waxes and penetration of glyphosate. p. 689-694. Proceedings of BCPC Conference-Weeds, Brighton, UK.

Singh, D., and M. Singh. 2008. Absorption and translocation of glyphosate with conventional and organosilicone adjuvants. Weed Biology and Management 8:104-111.

Slatyer, R. 1968. Environmental aspects of plant weather relationship. p. 40-46, 230-236. In Plant-weather relationship. $2^{\text {nd }}$ ed. Academic Press, New York, USA.

Smethurst, Q., and E. Nambiar. 1989. Role of weeds in the management of nitrogen in young Pinus radiata plantation. New Forest 3:203-224.
Verlag, R., A. Silva, A. Ferreira, and R. Miranda. 2003. Efeitos da chuva na eficiencia de formulacoes e doses de glyphosate no controle de Brachiaria decumbens. (Effect of rainfall on the efficacy of glyphosate formulations and doze in controlling Brachiaria decumbens). Planta Daninha 21:121-130.

Willard, T., D. Shilling, W. Haller, and K. Langeland. 1998. Physico-chemical factors influencing the control of torpedograss with glyphosate. Journal of Aquatic Plant Management 36:11-15.

Willoughby, I., and J. Dewar. 1995. The use of herbicides in the forest. Forestry Commission Field Book $\mathrm{N}^{\circ} 8$. HMSO, London, UK. 